\title{
Bases for the Establishment of Robusta Coffee (Coffea canephora) as a New Crop for Colombia
}

\author{
Luis F. Campuzano-Duque ${ }^{1}$, Juan Carlos Herrera ${ }^{2}$, Claire Ged ${ }^{2}$ and Matthew Wohlgemuth Blair ${ }^{3, *}$ (i) \\ 1 Corporación Colombiana de Investigación Agropecuaria (AGROSAVIA), \\ Villavicencio 500003, Departamento Meta, Colombia; lcampuzano@agrosavia.co \\ 2 Plant Science Research Unit-Nestle Research, 37100 Tours, France; \\ juancarlos.herrerapinilla@rdto.nestle.com (J.C.H.); claire.ged@rd.nestle.com (C.G.) \\ 3 Department of Agricultural and Environmental Sciences, Tennessee State University, \\ Nashville, TN 37209, USA \\ * Correspondence: mblair@tnstate.edu
}

Citation: Campuzano-Duque, L.F.; Herrera, J.C.; Ged, C.; Blair, M.W. Bases for the Establishment of Robusta Coffee (Coffea canephora) as a New Crop for Colombia. Agronomy 2021, 11, 2550. https://doi.org/ 10.3390/agronomy11122550

Academic Editors: Antonello Bonfante, Luca Brillante and Alessia Perego

Received: 14 November 2021 Accepted: 11 December 2021 Published: 15 December 2021

Publisher's Note: MDPI stays neutral with regard to jurisdictional claims in published maps and institutional affiliations.

Copyright: (C) 2021 by the authors. Licensee MDPI, Basel, Switzerland. This article is an open access article distributed under the terms and conditions of the Creative Commons Attribution (CC BY) license (https:/ / creativecommons.org/licenses/by/ $4.0 /)$.

\begin{abstract}
Robusta coffee (C. canephora) covers $36 \%$ of world coffee production and has strategic relevance as a beverage that it is produced by thousands of small-scale producers around the world. Although mainly grown in Africa and Asia as opposed to Latin America, this situation is changing. Colombia is recognized as a producer of high-quality Arabica (C. arabica L.) coffee, however we argue that Robusta represents a great economic opportunity for small scale producers, for the industrialization of new products and for emerging coffee chains. Therefore, the objective of this review is to outline the agronomic value of Robusta coffee as a "new crop" in Colombia. As background we compare the better-known Arabica to the Robusta coffees from a Latin American perspective. Robusta shows differences in geographical distribution, genetics, originating species, physiology and phenology. Robusta and Arabica also differ in their chemistry, sensory attributes, industrial use, segments of market and price. Despite the marked differences between the two coffees, the popularity and consumption of Robusta has been on the increase due to the expansion of markets in emerging economies and in developed markers for home espresso preparation where it is used in high quality coffee blends. Robusta is currently replacing areas of other coffees due to hotter temperatures to which it is adapted. Although Robusta is still new to Colombia, this species has potential adaptation in lowland areas considered "non-traditional" for Colombian coffee cultivation and as a valuable component of agro-ecological production systems. Robusta is a novel crop option for certain regions that is needed for the future of coffee in Latin America and for growth of coffee production and consumption in Colombia.
\end{abstract}

Keywords: agronomic adaptation; coffee blends; ecological regions; market opportunities; new crop

\section{Introduction to Difference between Robusta and Arabica Coffees}

Coffea canephora (syn. Coffea robusta), known as Robusta coffee, is a species from the Rubiaceae Family (Order Gentianales) that has its origins in central and western sub-Saharan Africa. Native to the tropical forests around Lake Victoria in Uganda, it was introduced to Southeast Asia in 1900 after leaf rust (Hemileia vastatrix Berk. and Br.) destroyed all of Ceylon's arabica coffee crops in 1869 and most of the low-lying plantations of Java in 1876 [1,2]. Currently, it represents $36 \%$ of world production and is grown in tropical countries from Indonesia and Vietnam, through Sub-Saharan Africa to Brazil.

The genetic structure of cultivated Robusta coffee parallels natural populations of C. canephora and in ex situ germplasm collections with specific studies by geographic regions, phylogenetic groups, phenotypic, biochemical, and molecular evaluations that determine the existence of wide genetic diversity with population structure composed of two groups: the Congolese group and the Guinean group. The Congolese group is subdivided into five subgroups: SG1, SG2, B, C, and UW. In the production chain of 
caffeinated coffee, those of the SG1 subgroup are known as C. canephora var. kouilou (in Brazil, known as conilon coffee), and the others are known as C. canephora var. robusta (or Robusta coffee) [3]. The Guinean group is less well studied.

Robusta differs from Arabica coffee in being two different sub-species, but also shows important differences in their origin, geographical distribution, genome conformation, ploidy level, genetic variability, morphology, physiology, and phenology (days to flowering, etc.), as well as in chemistry and organoleptic quality, industrial uses, market segments and price [4]. Table 1 shows 44 characteristics and/or attributes of Robusta and Arabica coffees, with the species $C$. canephora compared to C. arabica, recognizing that despite overall similarity between the two species as sources of coffee products there are many differences amongst them.

Table 1. Main differences between Coffea arabica and Coffea canephora.

\begin{tabular}{|c|c|c|}
\hline Specie & C. arabica, Arabica & C. canephora, Robusta \\
\hline Origin & Ethiopia, Sudan, Kenya & Guinea and Congo \\
\hline $\begin{array}{l}\text { Altitude of origin in meters above sea } \\
\text { level (masl) }\end{array}$ & $1300-2000$ & 0-1000 \\
\hline Genetic variability & $\begin{array}{l}\text { Low, due to its origin from few plants } \\
\text { and its self-pollinating condition. }\end{array}$ & $\begin{array}{l}\text { High, due to outcrossing } \\
\text { (natural interbreeding between and } \\
\text { within populations). }\end{array}$ \\
\hline Genetic structure & $\begin{array}{c}\text { Segmental allotetraploid } \\
\text { (cross C. eugenioides } \times \text { C. canephora) } \\
\text { Amphidiploid }\end{array}$ & $\begin{array}{l}\text { True Diploid with polymorphic } \\
\text { populations and highly heterozygous } \\
\text { heterotic groups }\end{array}$ \\
\hline Number of chromosomes & $2 n=4 x=44$ & $2 n=2 x=22$ \\
\hline Fertilization and compatibility & $\begin{array}{l}\text { Self-pollinated (more than } 90 \% \\
\text { autogamous) and self-compatible }\end{array}$ & $\begin{array}{l}\text { Self-incompatible gametophytic type } \\
\text { of monogenic nature and } \\
\text { synchronized flowering }\end{array}$ \\
\hline Plant type & Shrub & Tree and/or shrub \\
\hline Growth habit & Erect & Umbrella shape \\
\hline Propagation type & Sexual (seed) & $\begin{array}{l}\text { Asexual (cuttings-clonal) and } \\
\text { sexual (seed) }\end{array}$ \\
\hline Canopy structure & Pyramidal & Irregular \\
\hline Root type & Deep-rooted & Shallow-rooted \\
\hline Symbiotic associations & Dependent to obligate & Dependent, mycorrhizae obligate \\
\hline Stem type & Uni-caulate (woody) & Multi-caulate (woody) \\
\hline Grain-color (before roasting) & Greenish tone & Pale and yellowish tone \\
\hline Grain-shape (dry) & Larger, oval, flat and elongated & $\begin{array}{l}\text { Small, rounded, oval or elliptical; notable } \\
\text { tips; domed or convex }\end{array}$ \\
\hline Retention of grain by the plant & Lower & Higher \\
\hline Inflorescences (number) & Lower (2-3 peaks / crotch) & Higher ( $3-5$ peaks / crotch) \\
\hline Flowering (regularity) & Regular (after rains) & Irregular \\
\hline Flowering (months) & 9 & $10-11$ \\
\hline Photoperiod sensitivity (hours) & Short days (13.5) & Shorter days (11.0) \\
\hline $\begin{array}{l}\text { Grain earliness (months from anthesis to } \\
\text { fully ripe) }\end{array}$ & 6-8 (earlier) & 9-11 (later) \\
\hline $\begin{array}{l}\text { Time to induce the inactive } \\
\text { flowering-period (months) }\end{array}$ & $2-4$ & $2-4$ \\
\hline Biannual production & Present & Absent \\
\hline Latitude range (degrees) & Less than $10 \mathrm{~N}$ and $10 \mathrm{~S}$ & Between $10 \mathrm{~N}$ and $10 \mathrm{~S}$ \\
\hline
\end{tabular}


Table 1. Cont.

\begin{tabular}{|c|c|c|}
\hline Specie & C. arabica, Arabica & C. canephora, Robusta \\
\hline Optimal temperature $\left({ }^{\circ} \mathrm{C}\right)$ & $18-21$ & $22-30$ \\
\hline Optimum precipitation (mm) & $1500-2000$ & 2000-3000 \\
\hline Relative humidity required (\%) & $70 \%$ & $85 \%$ \\
\hline $\begin{array}{l}\text { Altitude for cultivation in meters above } \\
\text { sea level (masl) }\end{array}$ & $1000-2000$ & $0-700$ \\
\hline Genetic improvement scheme & $\begin{array}{l}\text { Hybridization, inbreed, backcross } \\
\text { (per autogamy) }\end{array}$ & $\begin{array}{l}\text { Reciprocal recurrent selection } \\
\text { (per allogamy) }\end{array}$ \\
\hline Yield $(\mathrm{kg} / \mathrm{ha})$ of green coffee & Usually lower performing (1500-3000) & $\begin{array}{l}\text { Higher performing ( } 2300-4000) \\
\text { with intensive production } 6000\end{array}$ \\
\hline Cherry (fresh): green coffee & Lower $(4: 1$ to $5: 1)$ & Higher (5:1 or above) \\
\hline Rust resistance & Susceptible & $\begin{array}{l}\text { Wide resistance spectrum } \\
\text { (source of resistance in Timor hybrid) }\end{array}$ \\
\hline Nematode resistance & Susceptible & Source of genetic resistance \\
\hline Planting density & High & Low \\
\hline Cup quality & Subtle taste, aromatic & Stronger taste, fragrant \\
\hline Caffeine content average $(\%)$ & 1.7 & $3.4(2 \times$ more content $)$ \\
\hline Isoflavones (micrograms) & 40 & $285(7 \times$ more concentrated $)$ \\
\hline Total reducing sugars (\%) & 0.10 & $0.40(4 \times$ higher $)$ \\
\hline Saccharose $(\%)$ & 8.0 & 4.0 (less than $50 \%$ ) \\
\hline Chlorogenic acid (\%) & $\begin{array}{l}\text { Green grain }(6.4-7.1) \\
\text { semi-ripe grain }(4.7-7.9) \\
\text { ripe grain }(5.5-6.9)\end{array}$ & $\begin{array}{l}\text { Semi-ripe grain }(7.8-8.0) \\
\text { ripe grain }(8.2-10.6)\end{array}$ \\
\hline Trigonellin (dry matter basis) & $0.79-1.06$ & $0.66-0.68$ \\
\hline Market segment & Premium and mainstream & Instant, blended coffees, washed \\
\hline Production cost & Higher & Lower (17\%) (no irrigation costs) \\
\hline Price & High & Low \\
\hline
\end{tabular}

When we compare the two coffees for production statistics, we see that Arabica is currently the dominant type. Arabicas represented $64 \%$ of world production in 2020/2021 with 6.1 million tons (measured as 101.9 million bags) produced. By comparison, Robusta coffee has a $36 \%$ market share, with 4.4 million tons (or 73.5 million bags) [5]. In terms of quality, Arabica is known for a pronounced aroma and acidity that is favored in the gourmet and international markets. Sometimes it is considered mild coffee. Robusta is known for having greater body but lower aroma [6], and it is consumed in emerging and developed markets as a mixed product or instant coffees.

The two types of coffee are planted in different geographical areas: Robusta in lowlands with high humidity and hot conditions, compared to Arabica under moderate temperatures of highland regions. Robusta is used as a substitute for Arabica in some places in mid-elevation Africa, lowlands of Asia, island nations and territories of the Caribbean (CARICOM) and the Pacific (Hawaii and Papua New Guinea), and increasingly in Latin America (notably Brazil and Mexico) given better adaptation to warm environment and resistance to leaf rust [7]. The edaphoclimatic conditions and the flat topography that occur in lowlands together with the architecture of the Robusta coffee plant allows potential mechanization and therefore higher productivity of this type of coffee [8]. This is important in Colombia and Brazil where labor prices are significantly higher than in Asia or Africa. C. canephora coffees, of either Robusta or Conilón type, can produce between 2 to $4 \mathrm{t} / \mathrm{ha}$ /year with a technological management, compared to 1.5 and $3 \mathrm{t} / \mathrm{ha}$ /year for Arabica. 
In the international market, the price of Robusta coffee is $25 \%$ lower than Arabica products, but this is offset by higher production, higher industrial conversion due to the high content of total soluble solids and a higher ratio of parchment "gold" beans compared to pulp or cherry. The Robusta beans are smaller, but heavier [9]. Most Robusta genotypes are resistant to rust and nematodes. Furthermore, they do not present biannual production, but rather provide either continuous monthly production or a single harvest per year in the case of synchronous varieties, which allows mechanization of all its cultural processes (depending on the topography of the region and variety) [10]. Arabica coffees sometimes produce in two seasons in regions with bimodal rainfall in Colombia and Kenya where they must be hand-picked by seasonal labor. Therefore, Robusta coffees can be more efficient to grow, allowing the problem of the low labor availability at picking times to be solved by mechanization or by employing labor that works continuously on Robusta along with harvesting other crops at other times of the year. This adapts Robusta to production on family farms.

\section{Possible Agro-Ecologies for Production of Robusta Coffee in Colombia}

Colombia is known for its production of high-quality "premium" 100\% Arabica coffees. This has been a mainstay of a national marketing campaign to promote coffee exports to Europe and North America from the South American country. Very little Robusta coffee has been produced in Colombia despite an internal market for the lower priced beans as compared to the Arabica which are selected and sent abroad. However, the situation of Arabica coffee is changing due to a series of societal and environmental factors.

Most importantly, the production areas for Arabica coffee in Colombia have been in decline in terms of overall area and green coffee yields; due to increasing limitations placed on Arabica coffee producers by climate change, the need for forest preservation and urbanization or divisional land holdings which squeeze the zone in which the crop can be grown into a smaller and smaller altitudinal zone between 1750 masl and 2000 masl. Traditional areas of Arabica coffee production in the Andean zone down to 1500 masl and up to 2250 masl are surrounded by high biodiversity and it is neither possible nor desirable to substitute higher elevation forested regions for coffee production. Meanwhile the potential production regions for Robusta coffee are growing and widespread [9].

Studies were undertaken by the project "Macro Café Canéfora" elucidating the future of this species as a new crop in Colombia by evaluating indicators of adaptation and ecoregional productivity. The goal was to determine if Robusta coffee would do well in non-traditional areas for coffee cultivation following the certain socio-economic guidelines: (a) expansion of the coffee zones across areas with a history of civil conflict violence, (b) areas with comparative and competitive advantages for Robusta production; (c) potential to increase per capita consumption and open new market niches in lyophilized instant coffees, and (d) potential uses of bioactive products in pharmaceutical and cosmetic products.

One of the first justifications for Colombia promoting the planting and production of Robusta is import substitution. Although little publicized, Colombia imports Robusta coffee to supply the needs of the domestic market. Colombia had a production in the $2020 / 2021$ period of 14.1 million bags with an unsatisfied internal demand of 2.2 million bags [5].

This unsatisfied domestic demand is half-way supplied by imported Robusta coffee (Table 2). These imports replaced products such as off-grade "pasilla" coffee that have been traditionally used in Colombia for domestic consumption and for the soluble and freezedried instant coffee industry. Robusta production locally in Colombia could substitute these imports [11] and therefore satisfy the needs of national coffee consumption. The participation of Robusta coffee to satisfy the estimated domestic demand in Colombia in 2021 would be 286,000 bags (2021), rising to 712,500 bags by 2025 [12]. The results of the study for demand of Robusta coffee in Colombia by Collazos et al. [12] are summarized in the table below. 
Table 2. Projection of domestic demand for coffee in Colombia 2021-2025 (million bags of $60 \mathrm{~kg}$ ).

\begin{tabular}{ccccc}
\hline \multirow{2}{*}{ Year } & \multirow{2}{*}{ Imports } & \multicolumn{2}{c}{ Domestic Consumption } & \multirow{2}{*}{ Total } \\
\cline { 3 - 4 } & & Arabica Coffee & Robusta Coffee & \\
\hline 2021 & 924,000 & 990,000 & 286,000 & $2,200,200$ \\
2022 & 921,140 & 998,086 & 417,764 & $2,332,000$ \\
2023 & 903,774 & 1039,217 & 519,609 & $2,462,600$ \\
2024 & 869,550 & $1,106,700$ & 658,750 & $2,635,000$ \\
2025 & 712,500 & $1,425,000$ & 712,500 & $2,850,000$ \\
\hline
\end{tabular}

In addition, Robusta produced in Colombia could be exported, considering that at present a good part of the world's instant coffee industry uses Robusta beans have higher overall green coffee yield but higher ratio of cherry to green coffee compared to Arabica beans. Robusta has high efficiency for industrialization based on high total soluble solids contents and other quality characteristics. Another advantage for producing Robusta coffee in Colombia is that it can be produced over a large land area at a low overall cost, even when comparing other countries in which this type of coffee bean is produced. Simulated production costs for Robusta type coffee in Colombia are $27 \%$ less per ton thank in Vietnam and Brazil [11]. One of the main comparative advantages is also open farmland availability. Colombia is blessed with many areas suitable for planting Robusta coffee both in the foothills of the Andes Mountains and on the humid Pacific and Caribbean coasts. Indeed, any region with unimodal precipitation that is higher than $2500 \mathrm{~mm} /$ year would be adequate for Robusta coffees. The rainy season in humid areas of Colombia is sufficient for non-irrigated coffee.

Water stress is a main limitation to Robusta coffee production and a major part of the cost structure in Vietnam and Brazil is taken up by irrigation needed across most phenological stages of the crop, representing $17 \%$ of farm costs. This indicates that the model for Robusta coffee in Colombia is under rainfed conditions with no supplemental water but in wet regions. High rainfall is an important comparative advantage of Colombia over further South American or Southeast Asian producers.

\section{Marketability and Further Production Advantages of Robusta Coffee from Colombia}

Robusta coffee demand has been increasing worldwide due to several factors: First, a greater expansion of emerging economies with a significant trend towards the consumption of soluble coffee. Second, the growing trend in the consumption of instant coffees worldwide, which has all resulted in a doubling in consumption of Robusta beans in the last twenty years. Third, coffee roasters have begun to make blends and mixtures that supply the North American market for single serving coffees. All this favors the use of Robusta due to its price and industrial conversion efficiency which is due to a higher degree of total soluble solids compared to Arabica. Shipping of Robusta coffee is favored by a cherry/green coffee ratio 5 and above compared to Arabica which is in the range of 4:1 to 5:1. Finally, worldwide coffee is increasingly consumed outside the home and the preparation of espresso has become fashionable, which mostly uses Robusta coffee [13].

An internal advantage for production of Robusta in Colombia, according to Leibovich and Llinás [11] is based on the prevalence of small to medium sized farms and the low competitiveness of other export crops in these areas (palm oil, corn and soybeans in Orinoquia and palms of various species in the Pacific region) in contrast to the comparative opportunity of Robusta coffee. In this regard, it is important to mention the maximum average values of the Family Agricultural Unit in each of the departments where the experimental crops of Robusta coffee can be established: Meta (696.34 ha), Córdoba (33.35 ha) and Nariño (13.3 ha). Additionally, the business of producing Robusta coffee is attractive since the price of imported material is US $\$ 2600$ per ton and the estimated production costs are US $\$ 1650$ to as low as $\$ 1100$ per ton, allowing a profit margin of at least $57 \%$.

In Colombia, research on coffee is mandated by the central government to be in the hands of the producers of this important signature crop. In this case, the Federation of 
Coffee growers, a nationally and regionally supported organization located in Manizales, Caldas set up Cenicafé (CC), as its research center in the early 20th century. As an institution CC conducts breeding on Arabica coffee and promotion of this type of bean. In their strategic framework, research on Robusta coffee is not prioritized. Therefore, germplasm of Robusta coffee has so far only been used in breeding to create interspecific hybrids between C. arabica X C. canephora for resistance to leaf rust (Hemileia vastatrix). However, CC introduced only 60 Robusta genotypes from Costa Rica during the 1970s, only evaluating them under field conditions such as those of Arabica coffee at the El Naranjal Experiment station [14]. That study was carried out in three trials $(1971,1975$, and 1978) under the names Canephora I, II and III. In each trial, 18 genotypes were evaluated in comparison with control varieties Borbón, Mundo Novo and Caturra, all C. arabica. In the three experiments, even under less than ideal conditions, the Robusta genotypes significantly out-yielded the Arabica controls starting from the second-year harvest and in the accumulated five-year period (Table 3).

Table 3. Average production in bushels/ha of 18 Robusta coffees and two varieties of Arabica coffee during five years of production (by harvest and accumulated as \% of Mundo Novo yields) from unpublished work [14].

\begin{tabular}{cccccccc}
\hline \multirow{2}{*}{ Species or Variety } & \multicolumn{9}{c}{ Year of Production } & Accumulated & Production \\
\cline { 2 - 6 } & $\mathbf{1}$ & $\mathbf{2}$ & $\mathbf{3}$ & $\mathbf{4}$ & $\mathbf{5}$ & $\mathbf{\%}$ \\
\hline Robustas $^{\text {Caturra }}{ }^{1}$ & 130 & 327 & 344 & 149 & 261 & 1209.8 & 139 \\
Mundo Novo $^{1}$ & 159 & 176 & 175 & 68.7 & 109 & 688.9 & 79 \\
L.S.D. $^{2}(0.05)$ & 134 & 246 & 185 & 169 & 138 & 871.9 & 100 \\
\hline
\end{tabular}

Footnotes: ${ }^{1} /$ : varieties of C. arabica. ${ }^{2} /$ : Least Significant Difference (L.S.D.).

The three initial trials were an important point in recognizing the yield potential of Robusta coffee in Colombia [14,15]; however, the introduced Robusta genotypes were evaluated in the regional conditions of an Arabica coffee production zone and unfortunately were not promoted in other regions. Green coffee yields of Robusta are known to reach 4000 to $6000 \mathrm{~kg} / \mathrm{ha}$ in other parts of the world. Therefore, there is a need for studying Robusta coffee in the lower elevation areas known to be recommended for this species. For this reason, the national government directly entrusted its national research arm of the Ministry of Agriculture now known as AGROSAVIA (previously as Corpoica) to estimate the feasibility of production in non-traditional areas outside the Coffee Zone. This initiative is called the "Coffee Mission", and is in charge of future testing of Robusta coffee.

\section{Potential Experimental Sites and Production Zones for Robusta Coffees in Colombia}

The Coffee Mission, mentioned above, includes experts from AGROSAVIA and the National Coffee Research Center. So far, it has conducted two studies to determine potential areas for Robusta coffee cultivation in non-traditional Arabica regions of Colombia with the required climatic characteristics $[15,16]$. In both studies, two important variables required for the growth of Robusta coffee were assumed: (1) precipitation would need to be 2000 to $3000 \mathrm{~mm}$ and with unimodal distribution that allows for a single annual harvest and possible mechanical harvesting and (2) average temperatures would be in the optimal ranges between 24 and $30^{\circ} \mathrm{C}$. Likewise, both studies coincided in defining three ecoregions with potential for cultivation: Orinoquia to the East, Pacific coast region to the West and humid Caribbean to the North of the country. Both studies emphasized the need for a research program into production constraints and varietal adaptation.

According to Herrón [15] when it comes to planting coffee in "non-traditional areas" it is very important to ensure that the selected areas comply with the environmental conditions that the plant requires for its normal growth and production. In the case of precipitation, the proximity of Colombia to Pacific Ocean currents and the layout of its mountain ranges, means that the rainfall has an intra-annual distribution in two totally 
different conditions, (1) Unimodal (with a single maximum peak in the year) or (2) Bimodal (with two maximum rainfall peaks in the year). The rainfall regimes with only one rainy period in the year occurred in the following regions: Eastern Plains and Amazon region with maximum rainfall in the months of June and July; and the Caribbean Plains, in the regions of influenced by the Northern Trade Winds such as the, Guajira and the Catatumbo River basin, where the rainfall peaks occur in the months of October and November.

Bimodal-type distributions occur in the regions where the Intertropical Confluence Zone (ITCZ) passes at two times of the year, with rain peaks in the months of April and May and in the months of October and November. This is the rain regime that occurs in traditional Arabica coffee growing areas. The areas that are selected for planting Robusta coffee must meet the characteristic of being Unimodal since it is an essential requirement to be able to concentrate a single annual harvest and thus be able to use the mechanical harvesting of the crop in the potential areas where the topography allows it [15].

In the second work carried out by Cenicafé [14], five non-traditional areas with adequate environmental offer for the potential production of Robusta coffee were identified, with a total potential area greater than 4.5 million hectares: (1) Cesar River valley (between the rancheria river and the Cesar River). Between 100 and $400 \mathrm{~m}$ above sea level, 4000 ha; (2) Sinú River Valley (between the Abibe and San Jeronimo mountains), between 100 and 200 masl., 10,000 ha; (3) Urabá (León River basin, municipalities of Turbo, Apartadó, Chigorodó), 100 masl., 20,000 ha; (4) Sabana de Torres (municipality of Sabana de Torres), 400 masl., 10,000 ha and (5) Orinoquía (Departments of Arauca, Casanare, Meta, Vichada), between 200 and 500 masl., 4.5 million ha.

Apart from the studies described above the national agricultural research system, AGROSAVIA (a.k.a Corpoica) conducted a preliminary review of Robusta coffee and reported the crop as: "a promising option to intensify and diversify production systems in the tropical lowlands of Colombia". The same entity carried out a third complementary study [16] that made it possible to determine, the Corporation's research centers in the country that could provide support for the first evaluations of Robusta coffee genetic based on the variables of altitude, temperature (maximum and minimum) and radiation (Table 4). A map of these centers' locations is shown in Figure 1.

Table 4. AGROSAVIA research centers suitable for the evaluation of Robusta coffee in Colombia.

\begin{tabular}{|c|c|c|c|c|c|}
\hline Research Center & Altitude (m) & $\begin{array}{l}\text { Minimum Average } \\
\text { Temperature }\left({ }^{\circ} \mathrm{C}\right)\end{array}$ & $\begin{array}{l}\text { Maximum Mean } \\
\text { Temperature }\left({ }^{\circ} \mathrm{C}\right)\end{array}$ & $\begin{array}{c}\text { Radiation } \\
\left(\mu \mathrm{mol} \text { photon } \mathrm{m}^{-2} \mathrm{~s}^{-1}\right)\end{array}$ & $\begin{array}{c}\text { Potential } \\
\text { Production }\end{array}$ \\
\hline Carimagua & 149 & 22.5 & 30.9 & $862.5-958.3$ & high \\
\hline El Mira & 21 & 22.6 & 29.3 & $670.8-766.6$ & high \\
\hline La Libertad & 340 & 21.5 & 29.6 & $862.5-958.3$ & high \\
\hline Motilonia & 111 & 23.3 & 33.5 & 958.3-1054.1 & high \\
\hline Nataima & 377 & 22.1 & 32.8 & $862.5-958.3$ & high \\
\hline Taluma & 168 & 22.3 & 31.0 & $862.5-958.3$ & high \\
\hline Turipaná & 11 & 23.5 & 32.4 & $766.6-862.5$ & high \\
\hline Caribia & 11 & 22.8 & 32.8 & 958.3-1054.1 & medium \\
\hline El Nus & 828 & 19.4 & 28.9 & $862.5-958.3$ & medium \\
\hline Palmira & 996 & 18.3 & 28.7 & $862.5-958.3$ & medium \\
\hline Cimpa & 1572 & 15.1 & 25.6 & $\mathrm{n} / \mathrm{a}$ & unsuitable \\
\hline La Selva & 2120 & 12.3 & 22.0 & $\mathrm{n} / \mathrm{a}$ & unsuitable \\
\hline La Suiza & 1628 & 15.6 & 23.3 & $\mathrm{n} / \mathrm{a}$ & unsuitable \\
\hline
\end{tabular}




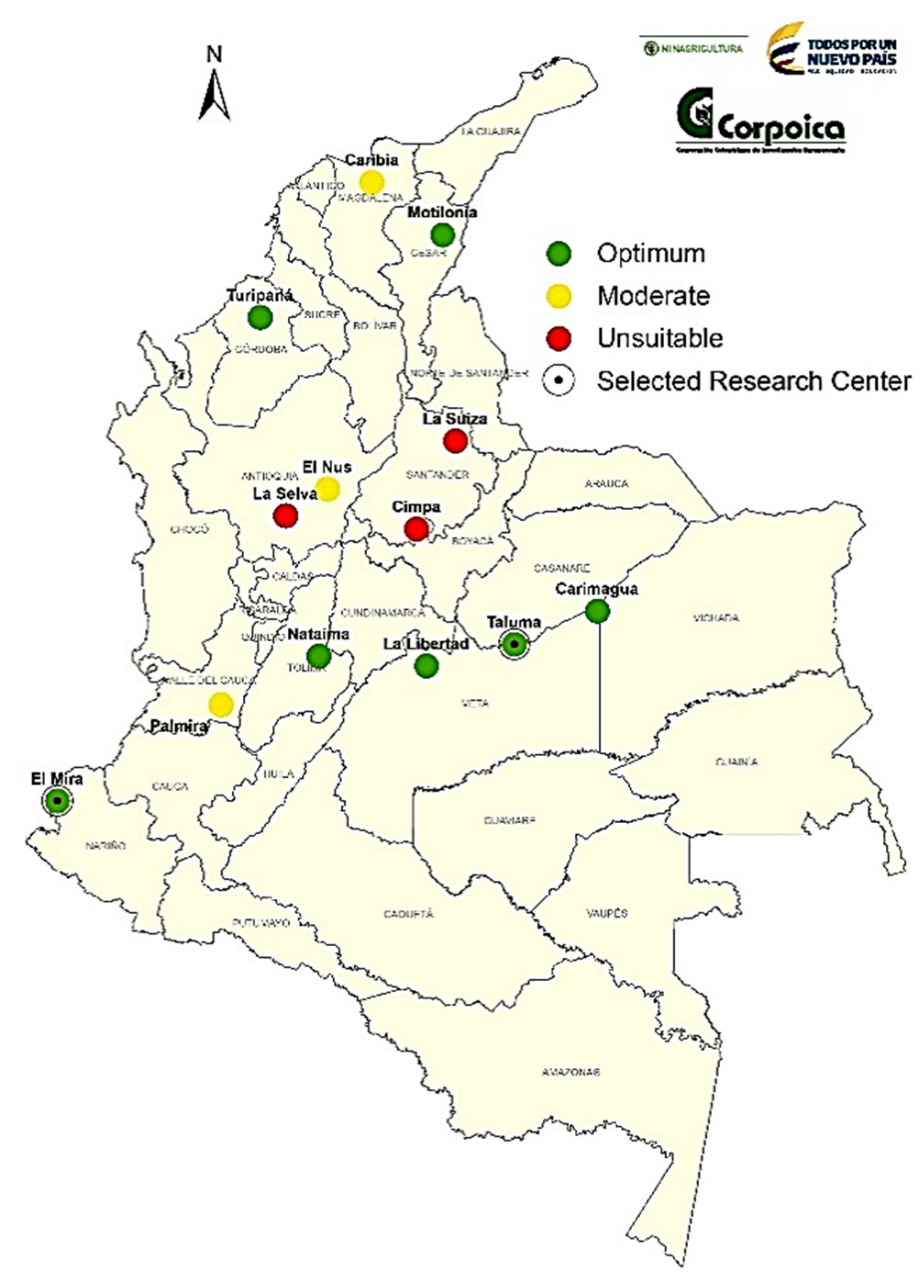

Figure 1. Optimal, moderate suitable and unsuitable National Agricultural Research System (AGROSAVIA, a.k.a Corpoica) experimental stations for the evaluation of Robusta coffees in the 32 political divisions (departments) of Colombia. Best selected research centers highlighted by bullseye.

Among the best centers to test Robusta coffee, the Taluma Experimental Station and the Carimagua Research Center are two representative sites for the soil conditions of the Colombian "altillanura". This is a region of flat terrain of moderate elevation (around 150 and 500 masl) adjacent to the Andes mountains that covers more than 4 million hectares and with a productive potential of 1.5 million in Robusta coffee, subtracting the foothill or high slope areas as unproductive. The soils are very acidic ( $\mathrm{pH}$ between 4.5 and 5.5), and have low base saturation, high aluminum saturation and high phosphorus binding capacity. However, the development of technologies for soil improvement has made it possible to overcome the physical and chemical limitations of the soil and its low fertility. As one advantage the soils are level, allowing for easy mechanization.

Research carried out by various partners for more than 30 years has allowed the generation of management technologies that have led to a notable increase in meat and grain production (soybean and corn) in the region [17]. The two stations of Carimagua and Taluma have similar average annual temperature of $26^{\circ} \mathrm{C}$ (average annual rainfall of $2400 \mathrm{~mm}$ ) and $26.8^{\circ} \mathrm{C}$ (average annual rainfall of $2135 \mathrm{~mm}$ ) respectively with relative humidity between 65 and 90\% [18]. Therefore, the Colombian "altillanura" presents good environmental conditions for the establishment of commercial Robusta coffee plantations. The region has experience in mechanization and improved soil management technologies. However, it is necessary to evaluate the accessions of the Robusta type under field condi- 
tions and evaluate the economic viability and sustainability of the system in the medium term ( 5 to 6 years).

Meanwhile representative of the Northern coastal region, the Turipaná Research Center, located at an altitude of $11 \mathrm{~m}$, is defined by an average annual temperature of $28^{\circ} \mathrm{C}$, with unimodal-bi-seasonal precipitation pattern (average annual rainfall of $1218.2 \mathrm{~mm}$ and monthly average of $101.5 \mathrm{~mm}$ ). The rainy season runs from May to October and represents $79 \%$ of the annual total; June has the highest recorded rain with $176.5 \mathrm{~mm}$ falling. The period of lower rain intensity is from November to April. January, with $12.6 \mathrm{~mm}$ falling, is the month with the least precipitation. Relative humidity averages $80.1 \%$ with very little variation throughout the year, with March being the month with the lowest value $(76.2 \%)$ and November the highest (83\%). The climate according to the Thornthwaite classification is $\mathrm{C}^{1} \mathrm{~d}^{\prime} \mathrm{A}^{\prime} \mathrm{a}^{\prime}$, semi-dry tropical forest with no water surplus. The potential evapotranspiration (ETP) values of the dry period are above the precipitation values and indicate a water deficiency of $544.6 \mathrm{~mm}$ that becomes noticeable between January and February. The month that presents the maximum ETP value is July with $162 \mathrm{~mm}$ and corresponds to the wet period; the minimum value of $132.8 \mathrm{~mm}$ is recorded in November.

Finally, among the best locations for Robusta research, the experiment station named El Mira is an AGROSAVIA research center representative of the humid tropical forest of the Pacific region of Colombia. Most soils are acidic Ultisols and Inceptisols with high clay content and variable soil fertility [19]. The station is located at an altitude of $16 \mathrm{~m}$, with a rainy season in the first months of the calendar year. The least rainy months are from July to November and a dry season occurs between the months of August and November. The average annual rainfall is $2792 \mathrm{~mm}$ /year. Annual average temperature is $26.1^{\circ} \mathrm{C}$ with a solar intensity of $1374.1 \mathrm{~h} /$ year. The temperature coincides with the summer of the southern hemisphere and maximum average value is $31.8^{\circ} \mathrm{C}$. Relative humidity presents an average value of $84.3 \%$; evaporation is $600 \mathrm{~mm}$ /year in the shade and $1000 \mathrm{~mm} /$ year outdoors. The landscape is dominated by native forests located on in hilly or flat terrain. Parts of the Cauca, Nariño and Valle de Cauca departments have similar coastal rain forest environments.

During the last few years, the Pacific Coast region has experienced a rapid expansion of oil palm and cocoa plantations under agroforestry systems or clear cutting by colonists growing coca to produce cocaine fueling a need for more legal alternatives for small farms. Robusta coffee could be planted as an addition to cocoa in the hillside regions. Together coffee and cocoa could be planted on 10,000 ha and become a substitute to replace the illicit production of coca that currently dominates the region.

\section{Regional Advantages and Limitations of Robusta Coffees in Colombia}

Several of the regions discussed have limitations but most have advantages overall for Robusta coffee. As for limitation in the Pacific zone, some of the flatter lowlands are prone to excess moisture that could limit plant growth. Growth of Robusta with cocoa in the same plot is not recommended as they have different shading requirements and both demand fertilization, competing in the same layer of topsoil for nutrients. However, being more deep-rooted than coca, the two tree crops would improve soil quality and protect the soils from nutrient loss which is occurring in the area.

The coffee management systems developed in the Amazon region of Brazil in the state of Rondonia in particular, based mainly on Robusta-type clonal varieties [20], is a reference for the viability and profitability of production model under similar agroecological conditions to this rain-forested area of Colombia.

Economically, Robusta coffee has great potential in lower altitude regions of Colombia. With investments, Robusta coffee in regions such as the Altillanura, the Pacific coast, the humid Caribbean region and Orinoquia, another rainforested region of Eastern Colombia, could replicate the development and well-being that Arabica coffee has brought to the highland Andean region for more than a century. A holistic approach to agricultural production would use Robusta coffee as an income generator and one of the pillars of 
small-scale agriculture in these areas. Robusta coffee production would not require large productive areas to be competitive and various production schemes could be proposed based on the size of the Family Agricultural Unit (FAU) in each region. For example, in the department of Meta the FAU averages 314 ha, in Casanare 140 ha and in Vichada 1237 ha.

Given the impressive tradition of coffee in Colombia, Robusta would not be starting from scratch, as there is a large body of knowledge that could be adapted to the production of this coffee in these potential regions and with new farming communities. Regarding the labor required in the production process, this may come in part from the small farm population of the region, or colonists/refugees coming in from other regions of Colombia. The possibility of involving ex-paramilitary and guerilla fighters trained to now grow Robusta coffee [9-13] would reintegrate these people into society. The achievement of higher incomes and safety compared to illicit crops was an essential part of the peace agreement signed between previous combatants and the national government. Likewise, Robusta coffee represents a chance to introduce on-farm small scale mechanization which would help all areas of agricultural productivity, another reason for the promotion of this "new" crop for Colombia.

A reasonable question for potential investors in the Orinoquia is the following: How profitable would the production of Robusta coffee be compared to current products and production systems? An approximate answer is given by Leibovich and Llinás [9]. Coffee generates more income than corn and soybeans, although it is much less than palm oil, with palm being more attractive from an income point of view. However, it is important to bear in mind that this crop in the Altillanura is not profitable in small areas of land, while coffee is (Table 5).

Table 5. Comparison between coffee and the representative productive systems of Orinoquía.

\begin{tabular}{cccc}
\hline Productive System & $\begin{array}{c}\text { Yield } \\
\text { (Mt/ha) }\end{array}$ & $\begin{array}{c}\text { Producer Price, 2011 } \\
\text { (USD/Mt) }\end{array}$ & $\begin{array}{c}\text { Income } \\
\text { (USD/ha) }\end{array}$ \\
\hline Robusta Coffee (DPC) & 0.91 & 4225 & 3845 \\
Maize/Corn & 4.50 & 434 & 1953 \\
Soybeans & 2.40 & 632 & 1517 \\
Palm oil & 3.1 & 1148 & 3100 \\
\hline
\end{tabular}

Source: Leibovich y Llinás [9]; DPC = dry parchment coffee; USD = United States Dollars.

Therefore, under the current regulatory framework and given the current debates on land tenancy, deforestation and farmland holdings in Colombia overall and more specifically on the Caribbean and Pacific coasts or in Orinoquía, it is very likely that palm expansion will be restricted while Robusta coffee planting will grow in the region. Oil palm is a strategic product for areas near processing plants but has been severely affected by phytosanitary problems such as bud decline. Likewise, in the areas where lack of commercial plantation crops or coca production are issues, the Robusta coffee crop could become an alternative to diversify agricultural production.

A breeding program to address the specific needs of each major area of possible production for Robusta coffee in Colombia is recommended [2]. For this, knowledge of diversity in the species is needed especially as there are different groups of $C$. canephora in the primary centers of origin in West and Central Africa $[3,21]$ along with additional germplasm of interest in secondary centers of diversity where the crop has a tradition of production such as in Brazil [22,23] and India [24]. A breeding program will have to consider adaptation plus current abiotic, biotic, climate-related and edaphic stresses [25]. Adaptation is suggested to be better for Robusta coffee production in Equatorial regions such as Colombia than in Central America, another Arabica growing region [26]. Southsouth technology transfer and technical exchanges from Indonesia and Vietnam in Asia may be useful for fertilization recommendations and agroforestry methods involving shade trees that may adapt to Colombian conditions $[27,28]$. Use of shade trees has also been studied in India and Uganda [29-31]. In the Americas, Brazil and Mexico, are also looking 
at growing Robusta in lower elevations. Wild Robusta coffees seem to have high diversity and adaptability [32-34].

\section{Conclusions}

Robusta coffee is originally from West Africa (DR Congo and Guinea) but has potential as lowland and heat stress environment germplasm for South America, especially in the equatorial areas that include most of warm-season Colombian agriculture. The crop is of interest in tropical regions where climate change is increasing temperatures at midelevations and pushing out highland Arabica coffee. Colombia is prominent in production of quality Arabica coffee and could also become a major producer of Robusta coffee. Compared to Arabica that is typically grown in central Colombia, Robusta can be grown along the Caribbean and Pacific coasts or in the Eastern lowland region of Orinoquía and the Altillanura. Robusta coffees have higher caffeine levels than Arabica and some organoleptic properties that could complement the high-quality beans grown in the country. This review discussed the benefits and limitations that Robusta coffee may have in Colombian production regions. Overall, the ecological adaptation of this "new" type of coffee makes them ideal for drought tolerance and they have natural resistance to some of the major pests and diseases of Arabica coffee allowing them to thrive under harsh conditions of drought or hotter-temperatures. Climate change is likely to further induce disease epidemics and insect spread. As a result, Robusta coffee is a promising new crop for production in Colombia. Like other countries in equatorial regions of Africa, Asia or the Americas, Colombia could have significant production for the domestic and foreign market of Robusta coffee given it has large areas suitable for this crop.

Author Contributions: Conceptualization, L.F.C.-D. and M.W.B.; methodology, L.F.C.-D. and J.C.H.; investigation, C.G., J.C.H., L.F.C.-D. and M.W.B.; data curation, L.F.C.-D. and J.C.H.; writing-original draft preparation, C.G., J.C.H., L.F.C.-D. and M.W.B.; writing-review and editing, J.C.H., L.F.C.-D. and M.W.B.; All authors have read and agreed to the published version of the manuscript.

Funding: This review was funded by Colombian Agricultural Research Corporation (AGROSAVIA), Ministry of Agriculture and Rural Development of Colombia (MADR), Nestlé and United States Department of Agriculture (USDA) National Institute of Food and Agriculture (NIFA) through the Evans Allen grant TENX-07. MWB was funded by a Fulbright Specialist grant to visit AGROSAVIA in 2019 and acknowledges ICETEX of Colombia and the State Department of the United States.

Institutional Review Board Statement: Not Applicable.

Informed Consent Statement: Not applicable.

Data Availability Statement: Data from this research can be made available by the corresponding authors upon request.

Conflicts of Interest: The authors declare no conflict of interest.

\section{References}

1. Coste, R. Coffee: The Plant and Products; Macmillan Press Ltd.: London, UK, 1992; 328p.

2. Montagnon, C.; Cubry, P.; Leroy, T. Amélioration génétique du caféier Coffea canephora Pierre: Connaissances acquises, stratégies et perspectives. Cah. Agric. 2012, 21, 143-153. [CrossRef]

3. Bikila, B.A.; Sakiyama, N.S.; Caixeta, E.T. SNPs Based Molecular Diversity of Coffea canephora. J. Microbiol. Exp. 2017, 5, 00136. [CrossRef]

4. Montagnon, C.; Guyot, B.; Cilas, C.; Leroy, T. Genetic parameters of several biochemical compounds from green coffee, Coffea canephora. Plant Breed. 1998, 117, 576-578. [CrossRef]

5. ICO. International Coffee Organization. Coffee Market Report 2021. Available online: https://www.ico.org/es/Market-Report20-21-c.asp (accessed on 1 October 2021).

6. Souza, C.; Rocha, R.; Alves, E.; Teixeira, A.; Dalazen, J.; Aymbiré, F.A. Characterization of beverage quality in Coffea canephora Pierre Ex A. Froehner. Coffee Sci. 2018, 13, 210-218. [CrossRef]

7. Herrera, J.C.; Alvarado, G.A.; Cortina, G.H.A.; Combes, M.C.; Romero, G.G.; Lashermes, P. Genetic analysis of partial resistance to coffee leaf rust (Hemileia vastatrix Berk \& Br.) introgressed into the cultivated Coffea arabica L. from the diploid C. canephora species. Euphytica 2009, 167, 57-67. 
8. Melese, Y.Y.; Kolech, S.A. Coffee (Coffea arabica L.): Methods, Objectives, and Future Strategies of Breeding in Ethiopia-Review. Sustainability 2021, 13, 10814. [CrossRef]

9. Buck, N.; Wohlt, D.; Winter, A.R.; Ortner, E. Aroma-Active Compounds in Robusta Coffee Pulp Puree-Evaluation of Physicochemical and Sensory Properties. Molecules 2021, 26, 3925. [CrossRef] [PubMed]

10. Rocha, R.B.; Ramalho, A.R.; Texeira, A.L.; Souza, F.d.F.; Cruz, C.D. Adaptability, and stability of Coffea canephora coffee bean yield. Cienc. Rural. 2015, 45, 1531-1537. [CrossRef]

11. Leibovich, J.; Llinás, G. La Producción de Café Robusta en Colombia. Econestudio/Asesoria y estudios académicos. 2013. Available online: https:/ / www.urosario.edu.co/Mision-Cafetera/Archivos/Produccion-de-Cafe-Robusta-Jose-Leibovich.pdf (accessed on 5 October 2021).

12. Collazos, E.; Piñeros, C.; Gutierrez, W. Estudio de Viabilidad Económica Para la Producción y Comercialización de Café Robusta (Coffea Canephora) en Colombia: Caso Sabana de Torres, Santander. Universidad Católica de Colombia Facultad de ciencias económicas y administrativas, Bogotá, Colombia. 2020. Available online: https:/ / repository.ucatolica.edu.co/bitstream/10983/ 24562/1/TRABAJO\%20FINAL\%20DE\%20GRADO\%20\%281\%29.pdf (accessed on 4 September 2021).

13. Holmes, M.J.; Otero, J. A tale of two coffees? Analyzing interaction and futures market efficiency. Stud. Econ. Financ. 2020, 37, 89-109. [CrossRef]

14. Alvarado, G. Atributos de valor de la especie Coffea canephora para la agricultura colombiana. 2017. Unpublished work.

15. Herron, A. Producción de Café en Áreas no Tradicionales. AherO Estudios Técnicos Agrícolas S.A.S. 2013. Disponible en. Available online: https://www.urosario.edu.co/Mision-Cafetera/Archivos/Zonas-no-tradcionales-antonio-Herron.pdf (accessed on 8 October 2021).

16. Ayarza, M.; Alvarado, G.; Castilla, C. Coffea canephora: A promising options to intensify and diversify production system in the tropical lowlands of Colombia. 2019. Unpublished work.

17. Garcia, O. Carimagua: La investigación y el desarrollo en ecosistemas de baja fertilidad. Rev. Colomb. Cienc. Pecu. 2009, 22, 74-78.

18. Podestá, P. Transformación Productiva de las Sabanas de la Altillanura Colombiana [en línea]. Trabajo Final de Ingeniería en Producción Agropecuaria. Facultad de Ciencias Agrarias. Universidad Católica Argentina. 2016. Disponible en. Available online: http:/ / bibliotecadigital.uca.edu.ar/repositorio/tesis/transformacion-productiva-altillanura-colombiana.pdf (accessed on 5 October 2021).

19. Ibarra-Ruales, L.; Reyes-Cuesta, R. Crecimiento en vivero de las palmas aceiteras Elaeis oleifera $\times$ Elaeis guineensis y Elaeis guineensis $\times$ Elaeis guineensis en Tumaco Colombia. Corpoica Cienc. Tecnol. Agropecu. 2015, 16, 239-250. [CrossRef]

20. Moraes, M.S.; Rocha, R.B.; Teixeira, A.L.; Espindula, M.C.; Silva, C.A.; Lunz, A.M.P. Adaptability and stability of Coffea canephora Pierre ex Froehner genotypes in the Western Amazon. Ciência Rural 2020, 50, e20190087. [CrossRef]

21. Kufa, T. Environmental sustainability and coffee diversity in Africa. In Proceedings of the InICO World Coffee Conference, London, UK, 3-8 October 2010; pp. 26-28.

22. Souza, F.D.F.; Caixeta, E.T.; Ferrão, L.F.V.; Pena, G.F.; Sakiyama, N.S.; Zambolim, E.M.; Zambolim, L.; Cruz, C.D. Molecular diversity in Coffea canephora germplasm conserved and cultivated in Brazil. Crop. Breed. Appl. Biotechnol. 2013, 13, $221-227$. [CrossRef]

23. Giles, J.A.D.; Partelli, F.L.; Ferreira, A.; Rodrigues, J.P.; Oliosi, G.; Silva, F.H. Genetic diversity of promising 'conilon'coffee clones based on morpho-agronomic variables. An. Acad. Bras. Ciências 2018, 90, 2437-2446. [CrossRef] [PubMed]

24. Prakash, N.S.; Combes, M.C.; Dussert SNaveen, S.; Lashermes, P. Analysis of genetic diversity in Indian robusta coffee genepool (Coffea canephora) in comparison with a representative core collection using SSRs and AFLPs. Genet. Resour. Crop Evol. 2005, 52, 333-343. [CrossRef]

25. Herrera, J.C.; Lambot, C. The coffee tree-Genetic diversity and origin. In The Craft and Science of Coffee; Academic Press: Cambridge, MA, USA, 2017; pp. 1-16.

26. Bunn, C.; Läderach, P.; Rivera, O.O.; Kirschke, D. A bitter cup: Climate change profile of global production of Arabica and Robusta coffee. Clim. Chang. 2015, 129, 89-101. [CrossRef]

27. Van Long, N.; Ngoc, N.Q.; Dung, N.N.; Kristiansen, P.; Yunusa, I.; Fyfe, C. The effects of shade tree types on light variation and robusta coffee production in Vietnam. Engineering 2015, 7, 742. [CrossRef]

28. Piato, K.; Lefort, F.; Subía, C.; Caicedo, C.; Calderón, D.; Pico, J.; Norgrove, L. Effects of shade trees on robusta coffee growth, yield and quality. A meta-analysis. Agron. Sustain. Dev. 2020, 40, 38. [CrossRef]

29. Nath, C.D.; Pélissier, R.; Ramesh, B.R.; Garcia, C. Promoting native trees in shade coffee plantations of southern India: Comparison of growth rates with the exotic Grevillea robusta. Agrofor. Syst. 2011, 83, 107-119. [CrossRef]

30. Kiyingi, I.; Gwali, S. Productivity and profitability of robusta coffee agroforestry systems in central Uganda. Uganda J. Agric. Sci. 2012, 13, 85-93.

31. Baggio, A.J.; Caramori, P.H.; Androcioli Filho, A.; Montoya, L. Productivity of southern Brazilian coffee plantations shaded by different stockings of Grevillea robusta. Agrofor. Syst. 1997, 37, 111-120. [CrossRef]

32. Cubry, P.; de Bellis, F.; Avia, K.; Bouchet, S.; Pot, D.; Dufour, M.; Legnate, H.; Leroy, T. An initial assessment of linkage disequilibrium (LD) in coffee trees: LD patterns in groups of Coffea canephora Pierre using microsatellite analysis. BMC Genom. 2013, 14, 10. [CrossRef] 
33. Gomez, C.; Dussert, S.; Hamon, P.; Hamon, S.; de Kochko, A.; Poncet, V. Current genetic differentiation of Coffea canephora Pierre ex A. Froehn in the Guineo-Congolian African zone: Cumulative impact of ancient climatic changes and recent human activities. BMC Evol. Biol. 2009, 9, 167. [CrossRef] [PubMed]

34. Akpertey, A.; Padi, F.K.; Meinhardt, L.; Zhang, D. Effectiveness of Single Nucleotide Polymorphism Markers in Genotyping Germplasm Collections of Coffea canephora Using KASP Assay. Front. Plant Sci. 2020, 11, 612593. [CrossRef] [PubMed] 